\title{
Evaluation of Forward Osmosis for Treatment of Sodium sulphate Rich Brine
}

\author{
T. M. Mogashane, J. P. Maree, N. Nyamutswa, J. Vogel, M. Mujuru and M. M. Mphahlele-Makgwane
}

\begin{abstract}
Acid Mine drainage (AMD), brines and other industrial effluents present an ever-increasing threat to the environment. In forward osmosis (FO), a new promising technology for wastewater treatment, water is driven through a semipermeable membrane from a feed solution to a draw solution due to the osmotic pressure gradient across the membrane. The aim of this study was to evaluate $\mathrm{FO}$ for the treatment of $\mathrm{Na}_{2} \mathrm{SO}_{4}$ rich brine with $\mathrm{NaCl}$ or $\left(\mathrm{NH}_{4}\right)_{2} \mathrm{SO}_{4}$ as the draw solution. Feed $\left(\mathrm{Na}_{2} \mathrm{SO}_{4}\right)$ and draw $\left(\mathrm{NaCl}\right.$ or $\left.\left(\mathrm{NH}_{4}\right)_{2} \mathrm{SO}_{4}\right)$ solutions were circulated through an Aquaporin Inside ${ }^{\circledR} \mathrm{HFFO} 14$ module in a counter cross-flow configuration. It was shown that when draw solution was passed through the FO element on a continuous basis while feed was recycled, permeate was passed through the membrane for as long as the osmotic pressure difference was large enough. The feed volume decreased by $73 \%$ during this period while the osmotic pressure (OP) difference between draw and feed solutions gradually decreased. Steady state conditions were obtained after $80 \%$ of the feed solution had passed through the membrane to the draw solution. Forward Osmosis can be used to concentrate a $\mathrm{Na}_{2} \mathrm{SO}_{4}$ feed solution as a first step towards water recovery from AMD.
\end{abstract}

Keywords - Forward osmosis, Draw solution, Osmotic pressure, Mine water

\section{BACKGROUND}

Acid Mine Drainage (AMD), brines and other industrial effluents present an increasing threat to the environment. Current treatment processes such as High-Pressure Reverse Osmosis (RO), Freeze Crystallization and Distillation have high capital and very high maintenance costs, are beset by scaling of membranes, are technically inadequate and/or produce other pollutants such as brine and sludge [1, 2]. Forward Osmosis has been extensively evaluated for wastewater treatment and seawater desalination in the past few years on pilot and small commercial plants [3, 4].

Manuscript received October 30, 2020. This work was supported by the THRIP Programme of dtic (Department of Trade, Industry and Competition.

T. M. Mogashane, J. P. Maree, M. Mujuru, M. M. Mphahlele-Makgwane are with Department of Water and Sanitation, University of Limpopo, Private Bag X1106, Sovenga, 0727, South Africa.

T. M. Mogashane is with the Department of Chemistry, University of Limpopo, Private Bag X1106, Sovenga, 0727, South Africa.

J. P. Maree ROC Water Technologies, P O Box 70075, Die Wilgers, Pretoria, 0041, South Africa

N. Nyamutswa is with Capricorn District Municipality, Polokwane, South Africa

J. Vogel is with Aquaporin, Nymøllevej 78, DK-2800 Kongens, Lyngby, Denmark
Forward osmosis (FO) is commonly used for separation in processes utilizing the osmotic pressure difference induced by the solute concentration difference between the feed and draw solutions. For an FO membrane to be effective, it must have high water permeability, reduced internal concentration polarization (ICP), high stability, exceptional selectivity, and high mechanical strength. The draw solution (DS) must also be nontoxic and possess the ability to bestow high osmotic pressure, offer energy efficient draw solute recovery, and decreased ICP $[4,6]$.

The FO process has several economic advantages over RO and in respect of power consumption. FO runs on the concentration difference between the DS and the Feed Solution (FS) since no external force is needed to push the water through the membrane. Energy is needed to maintain the cross-flow of the FS and DS so that the contact with the membrane surface is maintained and provides sufficient shear force to reduce the concentration polarization $(\mathrm{CP})[7,8]$. Draw recovery is usually an important feature in respect to energy.

FO uses spontaneous water transportation by osmotic pressure from the feed saline water to the draw solution across a semipermeable membrane. When FO is applied as a pre-treatment for the $\mathrm{RO}$ process, it can reduce membrane fouling at the RO stage and minimize energy use [9, 6]. FO then has a high potential to function in a seawater desalination plant using an FO-RO hybrid system. The FO-RO Hybrid Desalination Research Center (FOHC) has evaluated this combination, and constructed an FO-RO hybrid pilot plant of $1000 \mathrm{~m}^{3} /$ day capacity which has minimized energy consumption $[10,6]$.

In the FO process, clean water permeates the semipermeable membrane from the FS which accumulates in the DS, consequently diluting the DS and concentrating the FS. The major disadvantage of this technology is the need for additional step(s) to regenerate (re-concentrate) the DS to keep the required osmotic pressure gradient and also to further treat the concentrated FS [12]. Freeze desalination (FD) can possibly be used to further concentrate the Feed solution after FO. Recovery of high value products such as rare earth metals (REMs) which occur in low concentrations is also enabled by this process. As a result, the revenue from these saleable products can be used to offset the operational and capital costs of the process [13].

The most critical limitations to the commercialization of FO are: (i) the lack of suitable, high-flux membranes, and (ii) finding a suitable draw solution. An ideal FO membrane should 
have high water permeability and salt rejection, should be thin without a porous support layer reducing the $\mathrm{CP}$ effects, and must also have good mechanical strength $[14,15,13]$. Use of a thin membrane without support layers is problematic because it does not provide adequate mechanical strength to withstand the pressure of the water flow inside the membrane module. Several recent advances have been reported in membrane manufacturing. The thin film composite (TFC) FO membranes have been found to have much higher water flux and salt rejection properties than the current cellulose triacetate (CTA) FO membranes [16, 13]. The innovative claim for this TFC type is the modification of the support layer which is thinner and porous, making it more suitable for the FO process. In particular, the hollow fiber TFC FO membrane is a significant advance since flat sheet membranes make for complexity in the design of spiral-wound modules accommodating two different and independent flows in the module. With the commercialization of TFC-FO membranes, the future prospects of the FO process and its applications will be promising [17, 13].

In the design of FO systems, wide differences are observed in the selection of draw solution considering the potential of osmotic pressure build-up and ease of recovery [18]. Solutes with small molecular weights and high solubilities are expected to generate higher osmotic pressures and thus may result in better water flux [13]. Ammonium bicarbonate is highly soluble in water and generates high osmotic pressure and consequently, in solution, is often a good choice as draw solution. An ammonium bicarbonate draw solution has been used to extract water from saline feedwater across a semipermeable polymeric membrane where the saline feedwater and draw solution have been fed to the FO unit, which flows tangentially to the membrane in a cross-flow mode with concurrent direction $[11,19]$.

Common chemical fertilizers have been used in preparing draw solutions, and are another economically viable option for desalination of saline water as the diluted fertilizer draw solution, when "exhausted" can be directly applied to soil for agricultural purposes [20]. Of the mostly used fertilizers, $\mathrm{NH}_{4} \mathrm{H}_{2} \mathrm{PO}_{4}$ was found to have the lowest reverse salt flux (RSF), followed by $\left(\mathrm{NH}_{4}\right)_{2} \mathrm{HPO}_{4}, \mathrm{Ca}\left(\mathrm{NO}_{3}\right)_{2}$, and $\left(\mathrm{NH}_{4}\right)_{2} \mathrm{SO}_{4}$. Due to the presence of divalent anions, the ammonium compounds of sulfate and phosphate as well as $\mathrm{Ca}\left(\mathrm{NO}_{3}\right)_{2}$ are found to have very low RSF, which is important for any FO process. Preliminary estimates demonstrate that about $1 \mathrm{~kg}$ of fertilizer can be used to extract 11-29 L of freshwater from seawater $[9,11]$.

The detrimental effect of ICP on water flux in the FO process is increased further when solutes with low diffusivities such as magnesium, calcium, sulfate, and certain organic salts are used in the DS. Thus, the RSF can favorably be lower and the water flux unfavorably lower when using inorganic and organic DSs such as magnesium chloride, magnesium sulfate and trisodium citrate, compared to sodium chloride at the same osmotic pressures because of the lower diffusivity of the divalent and organic salts through the membrane's active and support layers.

An ideal DS produces high water fluxes just as those induced by $\mathrm{NaCl}$ and low RSFs like those observed when divalent inorganic and organic salts are used at common DS concentrations $[21,22,18] . \mathrm{NaCl}$ is an ideal DS for FO because of high water flux and low RSF as compared to other inorganic and organic DSs as described [18]. $\mathrm{NaCl}$ is also cheap and readily available. Thus, $\mathrm{NaCl}$ was used in this study in the Draw solution for treatment of $\mathrm{Na}_{2} \mathrm{SO}_{4}$ rich water and also to enhance FO by lowering reverse salt flux while maintaining high permeate flow.

\section{MATERIALS AND METHODS}

\section{A. Feedstock}

$\mathrm{Na}_{2} \mathrm{SO}_{4}\left(20 \mathrm{~g} / \mathrm{L} \mathrm{Na} \mathrm{SO}_{4}\right)$ was used as the Feed solution and $\mathrm{NaCl}(40,60,80 \mathrm{~g} / \mathrm{L})$ and $\left(\mathrm{NH}_{4}\right)_{2} \mathrm{SO}_{4}(80 \mathrm{~g} / \mathrm{L})$ as the Draw solutions.

\section{B. Equipment}

Figure 1 shows the FO system that was used for treatment of a $\mathrm{Na}_{2} \mathrm{SO}_{4}$ solution. The $\mathrm{FO}$ element was provided by Aquaporin A/S, Denmark with characteristics as shown in Table 1. Centrifugal pumps were used to run feed $\left(\mathrm{Na}_{2} \mathrm{SO}_{4}\right)$ to the $\mathrm{FO}$ element from the one side and draw solution $(\mathrm{NaCl}$ or $\left.\left(\mathrm{NH}_{4}\right)_{2} \mathrm{SO}_{4}\right)$ from the other side. Storage tanks (300L) were used for the feed and draw solutions.

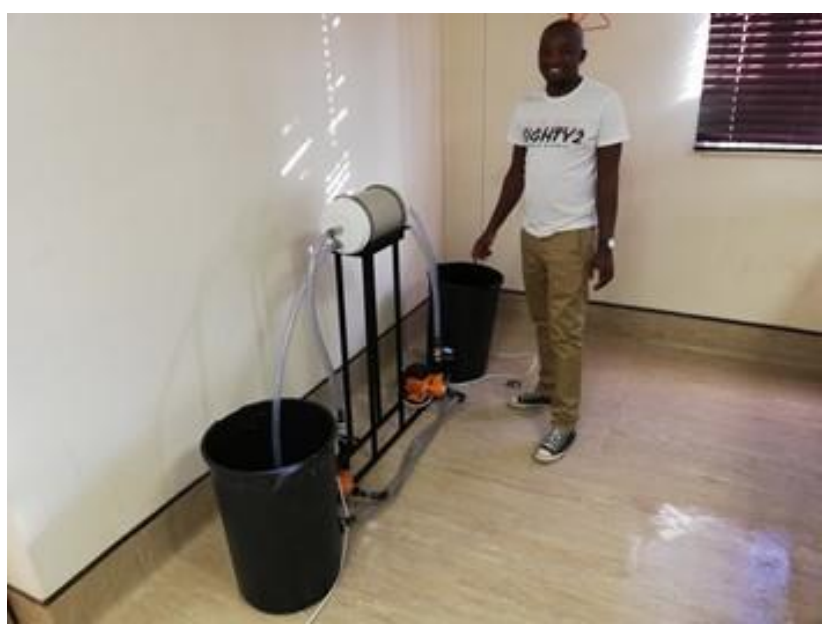

Fig. 1. Forward osmosis laboratory scale plant.: (i) stand, (ii) Forward Osmosis unit, (iii) Feed recycle pump A left (4.8 L/min), (iv) draw recycle pump B right (3.8 L/min) (v) Storage tanks for Feed $(300 \mathrm{~L})$ and draw solutions $(300 \mathrm{~L})$

\section{Analytical}

Samples were collected at various stages in the FO treatment processes and analysed. Capricorn Laboratory (SANAS accredited) did $\mathrm{pH}$, conductivity analyses. In addition chloride, ammonia and sulphate analyses were carried out by Ion Chromatography (IC). Sodium concentrations were determined using inductively coupled plasma-mass spectrometry (ICP-MS).

\section{Procedure}

Feed solution (20 g/L Na $\left.\mathrm{Na}_{4}\right)$, stored in Tank A, was recycled though the FO element. The Draw solution was pumped from Tank B through the FO element from the opposite side; either once through (Exp 6) or recycled and returned to Tank B (Runs 7, 8, 9 and 10). Both the feed and draw flow-rates were kept between 3 and $5 \mathrm{~L} / \mathrm{min}$. In order to 
maintain high water flux and lower reverse salt flux between experiments. The FO module was rinsed with de-ionised water for 20-30 mins from feed and draw sides, after use.

\section{E. Experimental}

The effects of the following parameters were investigated:

- Mode of draw flow: Once through or Recycle;

- Concentration of Draw solution: $40,60,80 \mathrm{~g} \mathrm{NaCl} / \mathrm{L}$;

- Type of Draw solution: $40 \mathrm{~g} / \mathrm{L} \mathrm{NaCl} ; 40 \mathrm{~g} / \mathrm{L}$ $\left(\mathrm{NH}_{4}\right)_{2} \mathrm{SO}_{4}$.

\section{F. Modelling}

The OLI ESP software program was used to predict the behaviour of osmotic pressure of various salts [23].

\section{RESUlTS AND DISCUSSION}

\section{A. Behaviour of feed and draw compounds}

Figure 2 shows the behaviour of various parameters of the feed $\left(20 \mathrm{~g} / \mathrm{L} \mathrm{Na} \mathrm{SO}_{4}\right)$ and draw $(60 \mathrm{~g} / \mathrm{L} \mathrm{NaCl})$ when treated with FO. It was observed that $66.1 \%$ water flow through the membrane from the Feed solution to the Draw solution occurred.

Both Feed and Draw solutions were recycled from their respective tanks. This flow of water resulted in an increase in the Feed $\mathrm{Na}_{2} \mathrm{SO}_{4}$ concentration. $\mathrm{SO}_{4}$ concentration (as $\mathrm{SO}_{4}$ ) increased from 14020 to $41320 \mathrm{mg} / \mathrm{L}$ and $\mathrm{Na}^{+}$concentration, from 7690 to $23515 \mathrm{mg} / \mathrm{L}$.

Simultaneously the $\mathrm{NaCl}$ concentration in the Draw solution was diluted as indicated by the drop in $\mathrm{Cl}^{-}$concentration from 41538 to $27590 \mathrm{mg} / \mathrm{L}$ and the $\mathrm{Na}^{+}$concentration from 26418 to $18570 \mathrm{mg} / \mathrm{L}$. The increase of the $\mathrm{Cl}^{-}$-concentration in the feed solution can be ascribed to reverse salt flux (see later section).

\section{B. Draw solution - single pass vs. batch mode}

During full-scale operation Feed and Draw solutions will normally flow in counter current directions to achieve maximum up-concentration of the Feed solution with associated dilution of the Draw solution.

In this investigation a single pass mode of operation was compared with batch mode operation for the Draw solution.

\section{1) Single pass operation}

For continuous flow of the Draw solution (Table 2 and Figure 3, red line) it was noted that: (i) $\mathrm{SO}_{4}$-concentration increased sharply during the first $60 \mathrm{~min}$ of operation (Figure 3.a, red line), which corresponded with a sharp dilution of the $\mathrm{Cl}^{-}$-concentration in the Draw solution (Figure 3.b, red line).

After the initial period of $60 \mathrm{~min}$, the $\mathrm{Cl}^{-}$-concentration of the Draw solution remained constant which indicated no further dilution by permeate. The rate of water flow through the membrane (yellow line) from the Feed solution to the Draw solution was directly linked to the behaviour of the Feed concentration. The Draw solution returned slowly to its initial concentration, while the $\mathrm{SO}_{4}$-concentation of the Feed solution slowly increased further.

TABLE I. Characteristics OF THE Module (HFFo14 Module)

\begin{tabular}{|c|c|}
\hline \multicolumn{2}{|l|}{ Product specifications HFF014 } \\
\hline Parameter & Detail \\
\hline Fibre ID & $0.2 \mathrm{~mm}$ \\
\hline Membrane area & $148.5 \mathrm{ft}^{2} / 13.8 \mathrm{~m}^{2}$ \\
\hline Water flux (DI vs. $1 \mathrm{M} \mathrm{NaCl}$ ) & $15 \pm 1$ \\
\hline Specific reverse salt flux & $0.15 \pm 0.05 \mathrm{~g} / \mathrm{L}$ \\
\hline \multicolumn{2}{|l|}{ Module characteristics } \\
\hline Membrane type & Aquaporin Inside® Hollow fiber \\
\hline Operating mode & Cross-flow, inside-out \\
\hline Outer/Inner diameter & $265 \mu \mathrm{m} / 195 \mu \mathrm{m}$ \\
\hline Housing materials & $\begin{array}{l}\text { Polyamide } \\
\text { Polypropylene } \\
\text { Polycarbonate }\end{array}$ \\
\hline Sealings & EPDM \\
\hline $\begin{array}{l}\text { Feed connector } \\
\text { Draw connector }\end{array}$ & $\begin{array}{l}\text { BSP } 1 / 2, ' \text { Female } \\
\text { BSP } 3 / 8, \text { Female }\end{array}$ \\
\hline Weight, dry & $4 \mathrm{~kg}(8.8 \mathrm{lbs})$ \\
\hline Weight, filled with liquid & $7 \mathrm{~kg}(15.4 \mathrm{lbs})$ \\
\hline \multicolumn{2}{|c|}{ Recommended operating conditions } \\
\hline Operating mode & Counter-current flow \\
\hline $\begin{array}{l}\text { Transmembrane pressure lumen } \\
\text { to shell (TMP) }\end{array}$ & $0.2 \mathrm{bar} / 2.9 \mathrm{psi}$ \\
\hline Temperature range & $5-30^{\circ} \mathrm{C} / 41-86^{\circ} \mathrm{F}$ \\
\hline $\begin{array}{l}\text { Operating } \mathrm{pH} \text { range (Long term } \\
\text { exposure) }\end{array}$ & $3-9$ \\
\hline Max. particle size & $50 \mu \mathrm{m}$ \\
\hline Max. feed inlet pressure & 4 bar / 58.0 psi \\
\hline Max. draw inlet pressure & 2 bar / 29.0 psi \\
\hline
\end{tabular}

This behaviour can be explained by the changes in osmotic pressure (OP) in the Feed and Draw solutions. Table 2 showed a maximum value for OP Dif of $22.9 \mathrm{~atm}$. at the beginning and decreased to its minimum value of $-1.3 \mathrm{~atm}$. after the initial period $(65 \mathrm{~min})$. Due to the continuous feed of the Draw solution, the Osmotic Pleasure Difference (OP Dif) value increased to between 5 and $15 \mathrm{~atm}$. This lower IP Dif resulted in a slower permeate flow rate (yellow line). This showed that during full-scale operation the flow rates and concentrations of the salts in the solutions should be such that the OP Dif is sufficient to allow an expected permeate flow rate.

\section{2) Batch operation}

During Batch mode operation a similar behaviour was observed as for the single pass procedure except for the following: The feed solution did not reach the same high concentration due to lower water recovery.

Better water recoveries were achieved when the Draw solution was operated in single pass mode than in batch mode.

During full-scale operation, both Feed and Draw solutions will need to follow single pass mode. Batch operation is best only for experimental studies. 


\section{Osmotic pressure difference}

Figure 4 shows the $\mathrm{OP}$ as a function of concentration in $\mathrm{g} / \mathrm{L}$ for various compounds [23]. It shows that the monovalent compounds have the highest OP and could therefore be used for Draw solutions. Table 3 shows the effect of $\mathrm{NaCl}$ concentration on the up-concentration of a $20 \mathrm{~g} / \mathrm{L} \mathrm{Na} \mathrm{NO}_{4}$ Feed solution. Increasing the $\mathrm{NaCl}$ concentration from $40 \mathrm{~g} / \mathrm{L}$ to $80 \mathrm{~g} / \mathrm{L}$ resulted in an increased water recovery from $53.4 \%$ to $71.4 \%$ or an increase in Concentration Factor (CF) from 2.2 to 3.9.

\section{Reverse salt flux}

\section{1) NaCl as Draw solution}

Reverse salt flux (RSF) needs to be kept to a minimum to avoid contamination of the feed solution. The chloride values in Table 3 (Feed), show the magnitude of reverse flow for when $\mathrm{NaCl}$ was used as the Draw solution. It showed that the $\mathrm{Cl}^{-}$ concentrations in the Feed, after equilibration had been achieved. It increased from 783 to $5070 \mathrm{mg} / \mathrm{L}$, as the initial Draw solution concentrations were increased from 40 to $80 \mathrm{~g} / \mathrm{L}$. It was concluded that with $\mathrm{NaCl}$ as Draw solution much contamination of the Feed will take place. This can be ascribed to the small diameter of $\mathrm{Na}^{+}$and $\mathrm{Cl}^{-}$ions It is therefore important to select a Draw solution that will allow minimum reverse flow.

\section{2) $\left(\mathrm{NH}_{4}\right)_{2} \mathrm{SO}_{4}$ as Draw solution}

Aqueous $\left(\mathrm{NH}_{4}\right)_{2} \mathrm{SO}_{4}$ was identified as a possible Draw solution with a low RSF [20]. An experiment was carried out to compare the RSF when $\left(\mathrm{NH}_{4}\right)_{2} \mathrm{SO}_{4}$ is used as Draw solution with $\mathrm{NaCl}$. A concentration of $80 \mathrm{~g} / \mathrm{L}\left(\mathrm{NH}_{4}\right)_{2} \mathrm{SO}_{4}$ was used as it has an OP of 36.0 atm (Figure 4) which is significantly higher than the $8.6 \mathrm{~atm}$. of $20 \mathrm{~g} / \mathrm{L} \mathrm{Na}_{2} \mathrm{SO}_{4}$.

Table 4 compares the performance of $40 \mathrm{~g} \mathrm{NaCl} / \mathrm{L}$ as with $80 \mathrm{~g}\left(\mathrm{NH}_{4}\right)_{2} \mathrm{SO}_{4} / \mathrm{L}$ as Draw solutions for the treatment of $20 \mathrm{~g}$ $\mathrm{Na}_{2} \mathrm{SO}_{4} / \mathrm{L}$ feed solution. The $40 \mathrm{~g} \mathrm{NaCl} / \mathrm{L}$ has an $\mathrm{OP}$ of 37.0 atm. compared to the 36.9 atm of $\left(\mathrm{NH}_{4}\right)_{2} \mathrm{SO}_{4}$. $\left(\mathrm{NH}_{4}\right)_{2} \mathrm{SO}_{4}$ performed better than $\mathrm{NaCl}$ as improved water recovery was achieved with $\left(\mathrm{NH}_{4}\right)_{2} \mathrm{SO}_{4}(60 \%$ vs. $53.7 \%)$ as well as a higher $\mathrm{CF}$ (concentration factor) (2.20 vs. 2.16).

In spite of the better water recovery with $\left(\mathrm{NH}_{4}\right)_{2} \mathrm{SO}_{4}$ as Draw solution, it was found to be unsuitable as a Draw solution due its high reverse salt flux. $\mathrm{NH}_{4}{ }^{+}$migrated through the membrane from the Draw solution to the Feed solution and $\mathrm{Na}^{+}$from the Feed to the Draw solution. This was indicated by the increase in the $\mathrm{NH}_{4}{ }^{+}$concentration from 100 to $5150 \mathrm{mg} / \mathrm{L}$ (as N) in the feed solution. $\mathrm{Na}^{+}$concentration did not increase in a ratio similar to that of $\mathrm{SO}_{4}{ }^{2-}$, as expected. It only increased slightly, from 7155 to $8150 \mathrm{mg} / \mathrm{L}$.

\section{CONCLUSIONS}

Single pass mode needs to be used during full-scale operation. During single pass mode of the Draw solution $73 \%$ water recovery was achieved compared to $60 \%$ in the case of batch mode.

Higher osmotic pressure resulted in higher water recovery i.e. $71.2 \%$ water recovery with $80 \mathrm{~g} / \mathrm{L} \mathrm{NaCl}$ compared to only $53.4 \%$ in the case of $40 \mathrm{~g} / \mathrm{L} \mathrm{NaCl}$.
Aqueous $\mathrm{NaCl}$ is more suitable than $\left(\mathrm{NH}_{4}\right)_{2} \mathrm{SO}_{4}$ solution as a Draw solution due to the higher reverse salt flux of $\mathrm{NH}_{4}{ }^{+}$.

Forward Osmosis can be used to concentrate a $\mathrm{Na}_{2} \mathrm{SO}_{4}$ feed solution with $\mathrm{NaCl}$ as the Draw solution.

\section{RECOMMENDATION}

Applications should be identified where seawater or seawater brine can be used as Draw solution when effluents need to be up-concentrated with the aim of recovering valuable products. Both are rich in $\mathrm{NaCl}$, which was found to be the ideal salt to be used in the Draw solution.

\section{ACKNOWLEDGEMENTS}

The authors thank the Department of Trade and Industry through The Technology \& Human Resources for Industry Programme (THRIP) for financial support and Aquaporin A/S, Denmark for providing membranes for this study.

\section{REFERENCES}

[1] Z. Li, R. V. Linares, S. Sarp and G. Amy, "Direct and Indirect Seawater Desalination by Forward Osmosis.," Membrane-Based Salinity Gradient Processes for Water Treatment and Power Generation, p. 245-272, 2018. https://doi.org/10.1016/B978-0-444-63961-5.00009-2

[2] N. Zikalala, J. P. Maree, C. Zvinowanda, V. Akinwekomi, T. Mtombeni and L. Mpenyane-Monyatsi, "Treatment of sulphate wastewater by freeze desalination," Desalination and Water Treatment, vol. 79, pp. 93-102, June 2017. https://doi.org/10.5004/dwt.2017.20927

[3] S. Zhao, L. Zou, C. Tang and D. Mulcahy, "Recent developments in forward osmosis: opportunities and challenges," J. Membr. Sci., vol. 396, pp. 1-21, 2012.

https://doi.org/10.1016/j.memsci.2011.12.023

[4] G. P. S. Ibrahim, A. M. Isloor and E. Yuliwati, "A Review on Current Trends and Future Developments on (Bio-) Membranes," pp. 199-214, 2019.

https://doi.org/10.1016/B978-0-12-813551-8.00008-5

[5] Y. Woo, S. Kim, H. Shon and L. Tijing, "Introduction: Membrane DesalinationToday, Past, and Future.," pp. 1-22., 2019. https://doi.org/10.1016/B978-0-12-813551-8.00028-0

[6] A. Altaee, A. Alanezi and A. Hawari, "Forward osmosis feasibility and potential future application for desalination," Emerging Technologies for Sustainable Desalination Handbook, p. 35-54, 2018. https://doi.org/10.1016/B978-0-12-815818-0.00002-3

[7] N. Abdullah, M. Tajuddin and N. Yusof, "Forward Osmosis (FO) for Removal of Heavy Metals," Nanotechnology in Water and Wastewater Treatment, p. 177-204, 2019. https://doi.org/10.1016/B978-0-12-813902-8.00010-1

[8] S. Phuntsho, H. Shon, S. Hong, S. Lee and S. Vigneswaran, "A novel low energy fertilizer driven forward osmosis desalination for direct fertigation: Evaluating the performance of fertilizer draw solutions," $J$ Membr Sci, vol. 375, pp. 172-81, 2011. https://doi.org/10.1016/j.memsci.2011.03.038

[9] L. Chekli, S. Phuntsho, J. Kim, J. Kim, J. Choi, J. Choi, J. Kim, S. Hong, J. Sohn and H. Shon, "A comprehensive review of hybrid forward osmosis systems: performance, applications and future prospects," Journal of Membrane Science, vol. 497, pp. 430-449, 2016. https://doi.org/10.1016/j.memsci.2015.09.041

[10] P. Nasr and H. Sewilam, "The potential of groundwater desalination using forward osmosis for irrigation in Egypt," Clean Techn Environ Policy, vol. 17(7), p. 1883-95, 2015. https://doi.org/10.1007/s10098-015-0902-4

[11] P. Nasr and H. Sewilam, "Fertilizer drawn forward osmosis for irrigation," Emerging Technologies for Sustainable Desalination Handbook, p. 433-460, 2018. https://doi.org/10.1016/B978-0-12-815818-0.00013-8

[12] S. T. Reddy, A. E. Lewis, G. J. Witkamp, H. J. M. Kramer and J. van Spronsen, "Recovery of Na2SO4-10H2O from reverse osmosis retentate 
by euctetic freeze crystallization technology," Chemical Engineering Research and Design, vol. 88, pp. 1153-1157, 2010.

https://doi.org/10.1016/j.cherd.2010.01.010

[13] R. Wang, L. Shi, C. Tang, S. Chou, C. Qiu and A. Fane, "Characterization of novel forward osmosis hollow fiber membranes," J Membr Sci, vol. $355(1-2)$, p. $158-67,2010$.

https://doi.org/10.1016/j.memsci.2010.03.017

[14] N. Yip, A. Tiraferri, W. Phillip, J. Schiffman and M. Elimelech, "High performance thin-film composite forward osmosis membrane," Environ Sci Technol, vol. 44, p. 3812-8, 2010 . https://doi.org/10.1021/es1002555

[15] S. Zhang, G. Han, X. Li, C. Wan and T. Chung, "Pressure retarded osmosis," Sustainable Energy from Salinity Gradients, p. 19-53, 2016. https://doi.org/10.1016/B978-0-08-100312-1.00002-X

[16] R. Holloway, R. Maltos, J. Vanneste and T. Cath, "Mixed draw Solutions for Improved forward osmosis performance," Journal of Membrane Science, 2015. https://doi.org/10.1016/j.memsci.2015.05.016

[17] P. Pal, "Water Treatment by Membrane-Separation Technology," Industrial Water Treatment Process Technology, p. 173-242, 2017. https://doi.org/10.1016/B978-0-12-810391-3.00005-9
[18] H. Ma and B. Hsiao, "Electrospun Nanofibrous Membranes for Desalination," Current Trends and Future Developments on (Bio-) Membranes, p. 81-104, 2019. https://doi.org/10.1016/B978-0-12-813551-8.00004-8

[19] T. Cath, A. Childress and M. Elimelech, "Forward osmosis: principles, applications, and recent developments," J Membr Sci, vol. 281, pp. 70-87, 2006. https://doi.org/10.1016/j.memsci.2006.05.048

[20] K. Bowden, A. Achilli and A. Childress, "Organic ionic salt draw solutions for osmotic membrane bioreactors," Bioresource Technol, vol. 122, pp. 207-216, 2012 https://doi.org/10.1016/j.biortech.2012.06.026

[21] J. Yong, W. Phillip and M. Elimelech, "Coupled reverse draw solute permeation and water flux in forward osmosis with neutral draw solutes," J Membrane Sci, vol. 392, pp. 9-17, 2012. https://doi.org/10.1016/j.memsci.2011.11.020

[22] OLI, "http://www.olisystems.com/.," 2311 2015. [Online]. [Accessed 2015].

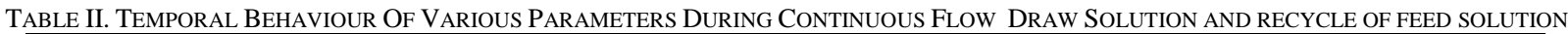

\begin{tabular}{|c|c|c|c|c|c|c|c|c|c|c|}
\hline \multirow[t]{2}{*}{ Time } & \multirow{2}{*}{$\begin{array}{c}\begin{array}{c}\text { Water } \\
\text { recovery }\end{array} \\
\%\end{array}$} & \multicolumn{3}{|c|}{ Feed solution } & \multicolumn{3}{|c|}{ Draw solution } & \multicolumn{3}{|c|}{ Osmotic Pressure (atm) } \\
\hline & & $\mathrm{Na}^{+}(\mathrm{mg} / \mathrm{L})$ & $\mathrm{SO}_{4}(\mathrm{mg} / \mathrm{L})$ & $\mathrm{Cl}^{-}(\mathrm{mg} / \mathrm{L})$ & $\mathrm{Na}^{+}(\mathrm{mg} / \mathrm{L})$ & $\mathrm{SO}_{4}(\mathrm{mg} / \mathrm{L})$ & $\mathrm{Cl}^{-}(\mathrm{mg} / \mathrm{L})$ & $\begin{array}{c}\text { Feed } \\
\mathrm{Na}_{2} \mathrm{SO}_{4}\end{array}$ & Draw NaCl & Difference \\
\hline 0.00 & 0.0 & 8188 & 16360 & 28 & 16085 & 1160 & 22385 & 8.6 & 31.6 & 22.9 \\
\hline 10.00 & 16.0 & 10450 & 21485 & 43 & 15025 & 1085 & 20830 & 11.1 & 29.4 & 18.3 \\
\hline 20.00 & 23.0 & 12265 & 24400 & 65 & 11028 & 770 & 14430 & 12.7 & 20.6 & 7.9 \\
\hline 35.00 & 28.0 & 12863 & 25125 & 78 & 8818 & 620 & 11485 & 13.1 & 16.3 & 3.1 \\
\hline 65.00 & 29.0 & 12163 & 24003 & 83 & 6478 & 463 & 8218 & 12.5 & 11.5 & 1.0 \\
\hline 85.00 & 29.0 & 12060 & 23695 & 90 & 6158 & 453 & 7968 & 12.4 & 11.1 & 1.3 \\
\hline 155.00 & 44.0 & 15363 & 30215 & 175 & 15935 & 1103 & 22445 & 15.7 & 31.5 & 15.8 \\
\hline 185.00 & 52.0 & 16915 & 33548 & 255 & 14230 & 995 & 19893 & 17.3 & 27.9 & 10.6 \\
\hline 235.00 & 59.0 & 19090 & 37955 & 398 & 13900 & 963 & 19310 & 19.5 & 27.2 & 7.6 \\
\hline 275.00 & 70.0 & 26140 & 50975 & 803 & 18730 & 1315 & 26940 & 26.3 & 37.7 & 11.4 \\
\hline 315.00 & 71.0 & 29305 & 54908 & 1085 & 17685 & 1218 & 24820 & 28.6 & 35.0 & 6.3 \\
\hline 340.00 & 73.0 & 28085 & $\begin{array}{llll}57 & 150\end{array}$ & 1250 & 17223 & 1195 & 23903 & 29.0 & 33.8 & 4.8 \\
\hline
\end{tabular}

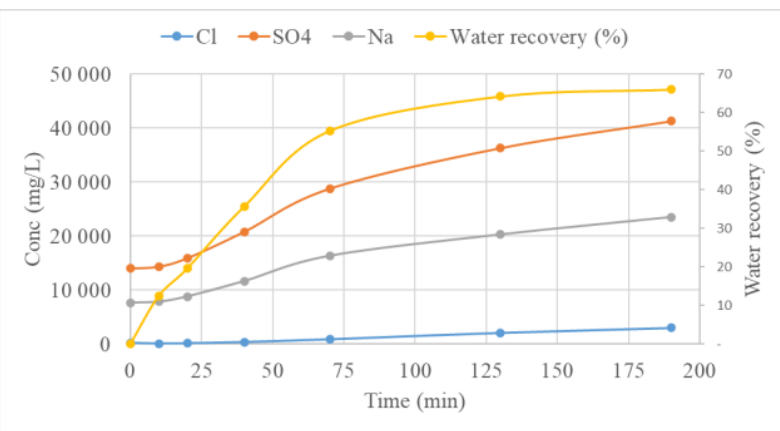

a. Feed solution

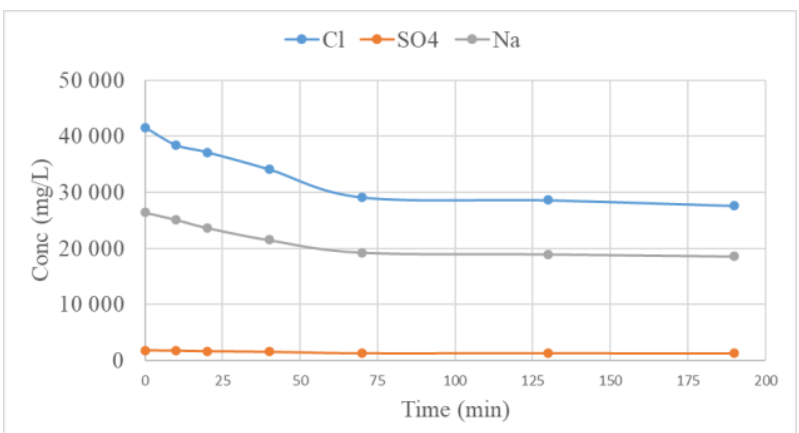

b. Draw solution

Fig. 2. Temporal behaviour of various parameters of Feed $\left(20 \mathrm{~g} / \mathrm{L} \mathrm{Na}_{2} \mathrm{SO}_{4}\right)$ and Draw $(60 \mathrm{~g} / \mathrm{L} \mathrm{NaCl})$ solutions (Feed - Recycled; Draw - Recycled)

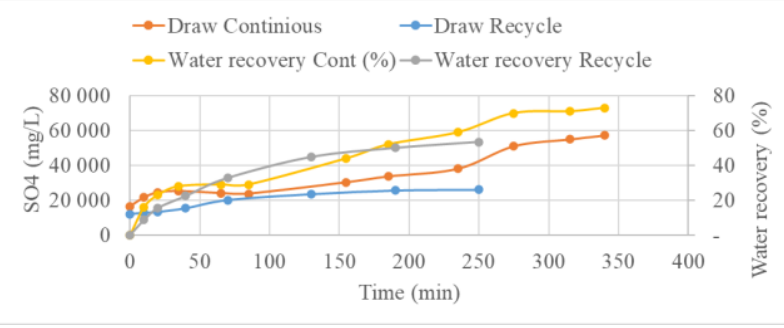

a. Feed solution

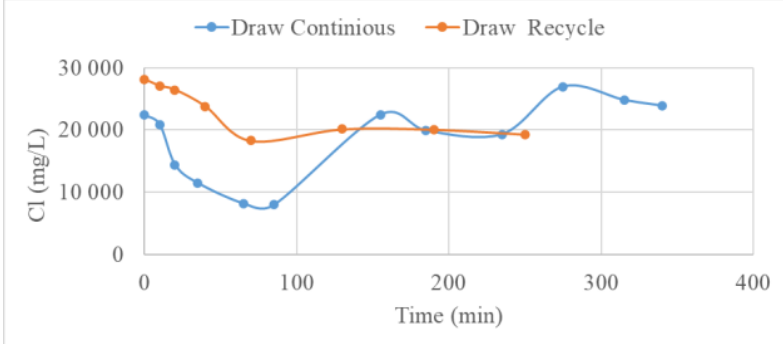

b. Draw solution 
Fig. 3. Effect of draw mode (Continuous or Recycle) on FO performance (Feed ( $20 \mathrm{~g} / \mathrm{L} \mathrm{Na}_{2} \mathrm{SO}_{4}$; Draw $(40 \mathrm{~g} / \mathrm{L} \mathrm{NaCl})$ )

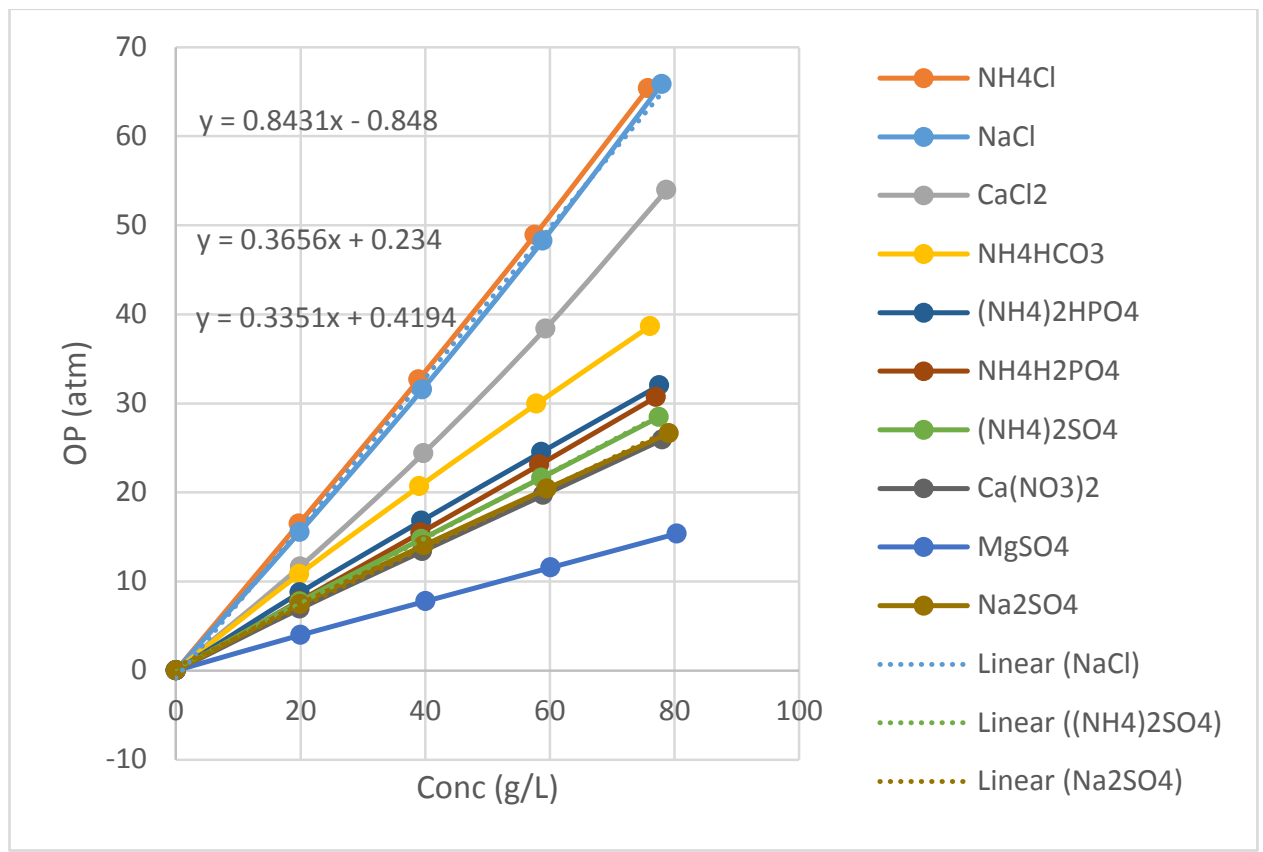

Trendlines:

$\mathrm{NaCl}$

Fig. 4. Osmotic pressure of various salts [23]

$\left(\mathrm{NH}_{4}\right)_{2} \mathrm{SO}_{4}$

0.843 x Conc. $(\mathrm{g} / \mathrm{L})-0.848$

$\mathrm{Na}_{2} \mathrm{SO}_{4}$

$0.366 \times$ Conc. $(\mathrm{g} / \mathrm{L})+0.234$

$0.3351 x$ Conc. $(\mathrm{g} / \mathrm{L})+419$ 
TABLE III. EFFECT OF OSMOTIC PRESSURE DIFFERENCE BETWEEN DRAW AND FEED SOLUTIONS ON WATER RECOVERY

\begin{tabular}{|c|c|c|c|c|c|c|}
\hline \multirow[t]{3}{*}{ Parameter } & \multicolumn{6}{|c|}{ Draw solution $(\mathrm{g} / \mathrm{L} \mathrm{NaCl})$} \\
\hline & \multicolumn{2}{|l|}{40} & \multicolumn{2}{|l|}{60} & \multicolumn{2}{|l|}{80} \\
\hline & Beginning & Equilibr. & Beginning & Equilibr. & Beginning & Equilibr. \\
\hline Water recovery $(\%)$ & & 53.4 & & 66.1 & & 71.4 \\
\hline Concentration factor & & 2.2 & & 3.4 & & 3.9 \\
\hline \multicolumn{7}{|l|}{ Feed } \\
\hline $\mathrm{Na}^{+}(\mathrm{mg} / \mathrm{L})$ & 6000 & 13490 & 7690 & 23515 & 8150 & 29208 \\
\hline $\mathrm{SO}_{4}{ }^{2-}(\mathrm{mg} / \mathrm{L})$ & 12053 & 26028 & 14020 & 41320 & 14260 & 46558 \\
\hline $\mathrm{Cl}^{-}(\mathrm{mg} / \mathrm{L})$ & 25 & 783 & 250 & 3000 & 718 & 5070 \\
\hline $\mathrm{OP}$ & 6.5 & 13.7 & 7.7 & 22.1 & 7.9 & 25.8 \\
\hline \multicolumn{7}{|l|}{ Draw } \\
\hline $\mathrm{Na}^{+}(\mathrm{mg} / \mathrm{L})$ & 16778 & 11770 & 26418 & 18570 & 38505 & 23208 \\
\hline $\mathrm{SO}_{4}{ }^{2-}(\mathrm{mg} / \mathrm{L})$ & 1225 & 885 & 1813 & 1273 & 2958 & 1785 \\
\hline $\mathrm{Cl}^{-}(\mathrm{mg} / \mathrm{L})$ & 28090 & 19275 & 41538 & 27590 & 59758 & 35798 \\
\hline \multicolumn{7}{|l|}{ Osmotic pressure } \\
\hline $\mathrm{OP}(\mathrm{atm})$ & 37.0 & 25.3 & 56.4 & 38.1 & 82.0 & 48.9 \\
\hline OP Difference (atm) & & 11.7 & & 18.4 & & 33.1 \\
\hline Exp & \multicolumn{2}{|c|}{7} & \multicolumn{2}{|c|}{8} & \multicolumn{2}{|c|}{9} \\
\hline
\end{tabular}

Note: Feed - Recycled; Draw - Recycled

TABLE IV. EFFECT OF DRAW SOLUTION (NACL OR $\left(\mathrm{NH}_{4} \mathrm{SO}_{4}\right.$ ) ON REVERSE FLOW OF SALT

\begin{tabular}{|c|c|c|c|c|}
\hline \multirow[t]{3}{*}{ Parameter } & \multicolumn{4}{|c|}{ Draw solution } \\
\hline & \multicolumn{2}{|c|}{$40 \mathrm{~g} / \mathrm{L} \mathrm{NaCl}$} & \multicolumn{2}{|c|}{$80 \mathrm{~g} / \mathrm{L}\left(\mathrm{NH}_{4}\right)_{2} \mathrm{SO}_{4}$} \\
\hline & Beginning & Equilibr. & Beginning & Equilibr. \\
\hline Time (min) & 0 & 250.00 & 0 & 260.00 \\
\hline Water recovery $(\%)$ & & 53.4 & & 60.0 \\
\hline Concentration factor & & 2.16 & & 2.20 \\
\hline \multicolumn{5}{|l|}{ Feed } \\
\hline $\mathrm{Na}^{+}(\mathrm{mg} / \mathrm{L})$ & 6000 & 13490 & 7155 & 8150 \\
\hline $\mathrm{SO}_{4}{ }^{2-}(\mathrm{mg} / \mathrm{L})$ & 12053 & 26028 & 14875 & 32768 \\
\hline $\mathrm{Cl}-(\mathrm{mg} / \mathrm{L})$ & 25 & 783 & & \\
\hline $\mathrm{NH}_{4}{ }^{+}(\mathrm{mg} / \mathrm{L})$ & & & 100 & 5150 \\
\hline $\mathrm{OP}$ & 6.5 & 13.7 & 7.8 & 13.0 \\
\hline \multicolumn{5}{|l|}{ Draw } \\
\hline $\mathrm{Na}^{+}(\mathrm{mg} / \mathrm{L})$ & 16777 & 12277 & 440 & 3175 \\
\hline $\mathrm{SO}_{4}{ }^{2-}(\mathrm{mg} / \mathrm{L})$ & 1225 & 905 & 69370 & 48180 \\
\hline $\mathrm{Cl}-(\mathrm{mg} / \mathrm{L})$ & 28090 & 20045 & & \\
\hline $\mathrm{NH}_{4}{ }^{+}(\mathrm{mg} / \mathrm{L})$ & & & 22125 & 13000 \\
\hline \multicolumn{5}{|l|}{ Osmotic pressure } \\
\hline $\mathrm{OP}(\mathrm{atm})$ & 37.0 & 25.3 & 36.0 & 23.7 \\
\hline OP Difference (atm) & 30.5 & 11.7 & 28.2 & 10.7 \\
\hline
\end{tabular}

